\title{
Indigenous Art and Sovereignty Inspiring Change against Environmental Degradation
}

\author{
Estelle Castro-Koshy
}

(iD) https://orcid.org/0000-0003-0853-2485

James Cook University, Australia

\section{Géraldine Le Roux}

https://orcid.org/0000-0001-5874-9653

Université de Bretagne Occidentale, France

\begin{abstract}
This special issue on "Environmental Artistic Practices and Indigeneity: In(ter)ventions, Recycling, Sovereignty" constitutes a body of creative contributions and academic articles addressing numerous forms of artistic practices of the Pacific Islands, Australia, French Guiana, the Caribbean, and Southeast Asia. Inspired by Indigenous artists and writers whose practices and creativity help reimagine sustainable ways to inhabit the world, this introduction and our special issue interrogate contemporary environmental issues and the legacy of colonisation. They examine how Indigenous artists and writers, and artists working with Indigenous artists and communities, have for decades raised awareness about environmental issues, and encouraged people to regain their agency to struggle against environmental degradation and further destruction of Indigenous people's societies and health. This introduction contextualises the concepts and Indigenous terms used by artists to express their vision of what a respectful relationship with the environment would be. It also offers readings of the beautiful literary and artistic creative contributions included in this issue. Environmental themes such as waste recycling, health issues, pollutants (mercury, POPs), and agricultural technics are discussed here in light of human and non-human life and agency. This issue also features a significant range of calls for action to better protect and restore ecosystems.
\end{abstract}

Keywords: Sovereignty, art, Indigenous, pollution, oceans, rivers, Asia-Pacific, French Guiana, Caribbean

eTropic: electronic journal of studies in the tropics publishes new research from arts, humanities, social sciences and allied fields on the variety and interrelatedness of nature, culture, and society in the tropics. Published by James Cook University, a leading research institution on critical issues facing the worlds' Tropics. Free open access, Scopus, Google Scholar, DOAJ, Crossref, Ulrich's, SHERPA/RoMEO, Pandora, ISSN 1448-2940. Creative Commons CC BY 4.0. Articles are free to download, save and reproduce. Citation: to cite this article include Author(s), title, eTropic, volume, issue, year, pages and DOI: $\underline{\text { http://dx.doi.org/10.25120/etropic.19.1.2020.3737 }}$ 
This issue is dedicated to Sam Watson (1952-2019), renowned writer, political warrior, community leader, family man, and friend to many.

$\mathrm{A}$ nalysing creative practices by Indigenous artists, or artists working closely with Indigenous communities, this pluridisciplinary issue aims to determine how Indigenous societies perceive and interact with pollution and toxic substances that affect their environment and territories. We initiated this special issue to examine how conceptions of waste and its recycling enlightens discourses on Indigenous sovereignty, and in turn, explore how the notion of sovereignty - as understood, lived, and defined by Indigenous peoples - informs and influences artistic practices that respond to contemporary environmental challenges. We also aim to substantially focus on how Indigenous people relate to rivers, the seas, the oceans, and the coastline. "Indigenous people" is used here according to the understanding developed by Indigenous representatives at the United Nations. ${ }^{1}$ The world comprises over 400 million Indigenous people (Bellier, 2013, p. 21), who speak an estimated 5,000 languages. At the United Nations, Indigenous representatives emphasise their respective singularities while reflecting on their commonalities in order to find "solutions to issues that affect the entire planet, and call us to change our economy and lifestyles" (Glowczewski, 2017, p. 17). It is our hope that this issue contributes to this discussion.

This special issue on Environmental Artistic Practices and Indigeneity features contributions addressing numerous forms of artistic practices of the Pacific Islands, Australia, French Guiana, the Caribbean, and Southeast Asia. It includes academic papers that examine Indigenous artistic, environmental, and livelihood practices, and features creative works by Indigenous writers and artists, including multi-awarded writers. This special issue also includes works by artists working closely with Indigenous communities and scholars. It is widely illustrated with photographs and artworks. The electronic format of the journal has also made it possible to include an original song that accompanies a poetic essay and artwork.

This thematic issue of eTropic expands upon research previously conducted by the two guest editors, Estelle Castro-Koshy and Géraldine Le Roux. Estelle Castro-Koshy is a scholar of literatures and cultural studies who has worked with Indigenous Australian writers, performers, and filmmakers since 2003, and Indigenous French Polynesian and Oceanian writers and artists since 2006. Géraldine Le Roux is an anthropologist, art historian, and art curator, who has worked with Indigenous Australian and Pacific artists for over 15 years and has published on the recycling of

\footnotetext{
${ }^{1}$ See for example https://www.un.org/development/desa/indigenouspeoples/about-us.html
} 
ghost nets by Indigenous artists from the tropical north of Australia. This issue is an integral part of a multi-form project seeking to articulate reflections about pollution, recycling, art, and Indigenous sovereignty. One part of this project was developed by Géraldine Le Roux in collaboration with the Centre des Métiers d'Art of French Polynesia (CMA): Le Roux curated an exhibition entitled Maeva. Polynesian Contemporary Art from Tahiti and French Polynesian islands in December 2019. The exhibition was structured around two sections: one section responded to the celebration of the centenary of the death of author, Victor Segalen; the second explored the CMA artists' understandings of pollution. Additionally, in early 2020, Géraldine Le Roux embarked on a 17 day sailing journey across the Pacific, starting from Rapa Nui and ending in French Polynesia, as a crew member of eXXpedition, a company pioneering all-female sailing research expeditions to investigate the causes of, and solutions to, ocean plastic pollution. ${ }^{2}$ One of the final aspects of this project will be an international conference co-organised by Estelle Castro-Koshy and Géraldine Le Roux, with Associate Professor Jean-Marc Serme at the University of Bretagne Occidentale, France, in $2021 .^{3}$

Social science shows a growing interest in "waste", also defined as "discarded materials", "litter", "remains" (Joulian, Tastevin \& Furniss, 2016). Studies have examined what our rubbish bins say about us (Rathje \& Murphy, 1992) and what recycling processes are undertaken by individuals (Duclos, 2015), artists (Laviolette, 2006), or institutions and industries. R. J. Garcier, for example, has analysed the recycling of metal and toxic residues (2014). Plastic pollution and marine pollution and their impact on biodiversity and people's health - are increasingly studied by scientists, scholars, and organisations. As an outcome of significant media coverage and documentaries that have focused on marine plastic pollution, people are becoming aware of this particular issue, but the need to radically question and limit the sourcing and production of plastic has received little attention (see for example The Story of Plastic, Schlosberg, 2019). Although all research and environmental reports call for emergency actions to be taken worldwide to limit fossil fuel extraction, air pollution, and plastic waste, the amount of plastic production and plastic pollution in the oceans is predicted to continue to increase in the next decades. Environmental issues often involve a variety of stakeholders, encompass expansive geographies, and defy national or state borders. They can appear to be difficult to address at the individual level because of their scale, or their complexity: for example, the distribution, circulation, and accumulation of marine waste on shore and in the water is affected by multiple factors at different levels - on the surface, in the water column and on the sea floor (Derraik, 2002; Jambeck et al., 2015; Galgani et al. in Bergmann, 2015). These

\footnotetext{
${ }^{2}$ https://exxpedition.com/about/about-us/

3 Originally planned to take place in November 2020, the conference was postponed due to the COVID-19 pandemic.
} 
contributing factors include an increasing consumption of plastic and junk food, a lack or weakness of waste infrastructures, the importation of waste from overseas and the dispersal of waste through river networks (Lebreton et al., 2017). Indigenous artists, and artists working with Indigenous artists and communities, have for decades been leading the way in raising awareness about the brutal force with which fossil fuel, mining, and other polluting companies or activities degrade Indigenous territories, or with which countries have used nuclear testing in lands far away from where their own populations live (Keown, 2018). They have challenged profit-driven individuals, politicians, and companies to change their behaviour, and encouraged people to regain their agency to struggle against environmental degradation and further destruction of Indigenous people's societies and health.

For this special issue, we wanted to examine artistic approaches deployed in or around spaces faced with different kinds of pollution and waste. How do artists speak about the journey of waste - for example due to marine currents, rivers or human actions? Is waste treated as exogamic or endogamic material? Is waste perceived as a negative effect of consumerism in society, or taken in some contexts as potentially interesting material that can be valued like any local natural resources?

Géraldine Le Roux's study (2016a), for example, has demonstrated that such a redefinition of plastic from waste to interesting material took place with the recycling of ghost nets in northern Australia and the Torres Strait Islands. She has shown that artists invite us to see ghost nets as a source of marine pollution that can be both visually impressive (the global circulation of massive pieces of nets) and an almost invisible phenomenon (the decomposition of the nets into micro-particles). This artistic intervention transforms the representation of fishing nets from "old", "dirty", anonymous and "non-desirable" "rubbish" into a potential art material which can be collected on the shores, and purchased or acquired through trade and gift-giving processes (2016b, p. 15). This can be seen in the image below. Figure 1. Crocodile, is an example of one of the first large ghostnet sculptures initiated by GhostNets Australia. This large artwork was made collaboratively by Torres Strait Islander artists from Hammond (Frank Petero, Georgia Curry), Moa (Angela Torenbeek), and Erub (Jimmy K. Thaiday), as well as non-Indigenous collaborators of GhostNets Australia (Cecile Williams, Karen Hethey, Sue Ryan, Greg Adams, Riki Gunn, and Jen Goldberg) in 2011. 


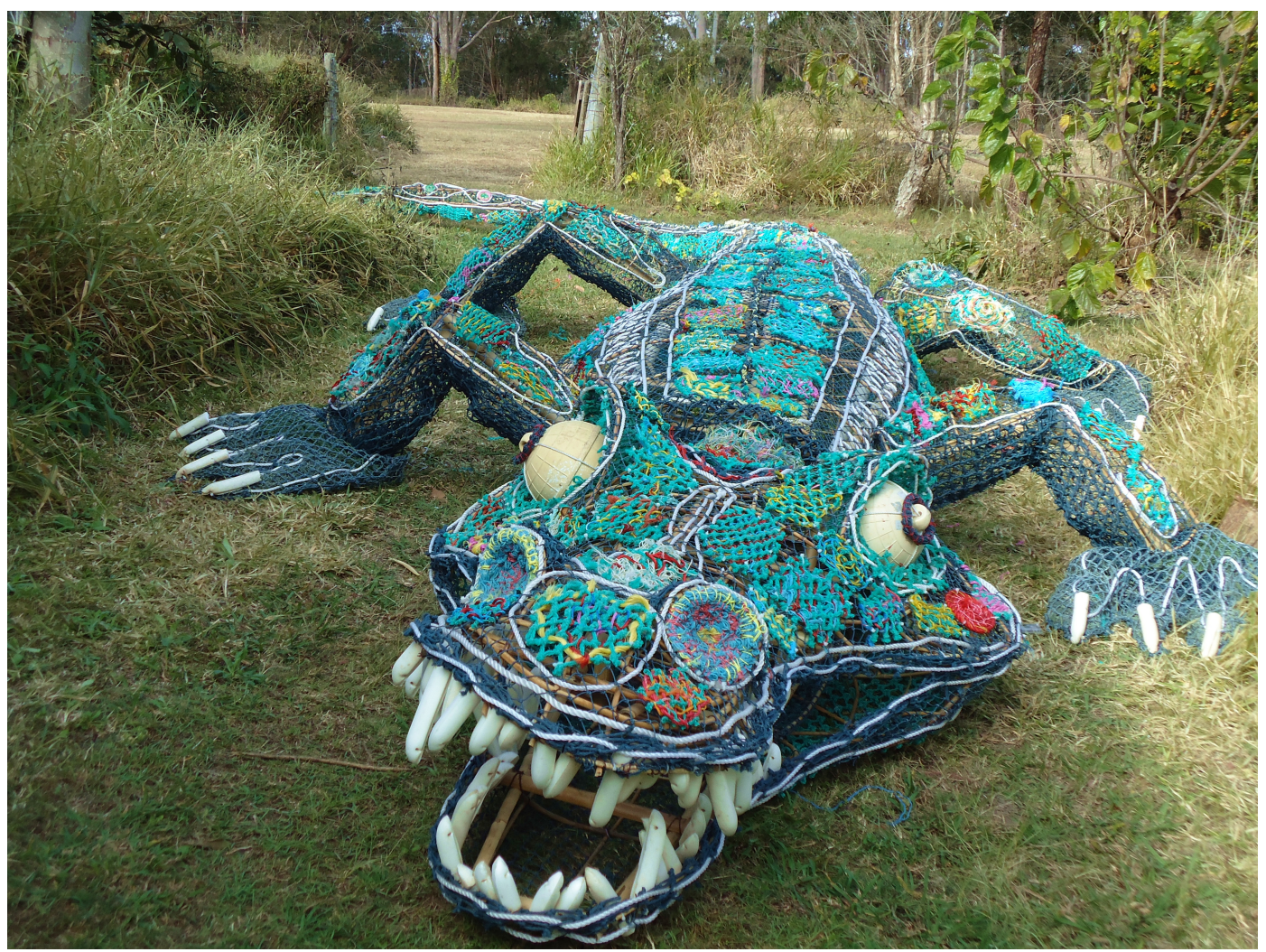

Figure 1. Crocodile (2011). Fishing gear and marine waste.

Photo: G. Le Roux @ GhostNets Australia

In this special issue, our aim is to foreground how Indigenous artistic practices and creativity can help reimagine sustainable ways to inhabit the world. This aim was inspired by the artwork and its accompanying poetry exhibited by Flora Aurima Devatine during the Exposition 'Ōrama in Papeete, Tahiti in 2017. A selection of works from the exhibition are published here in her poetic-photographic essay. We want to interrogate how elements collected on the beach, for example, inspire artistic - visual, filmic, poetic - works, and how such works can become, in Aurima Devatine's words, "re-building stones" that support and reveal a philosophical approach regarding the evolution of society. For the exhibition, Maeva. Polynesian Contemporary Art from Tahiti and French Polynesian islands in December 2019, Indigenous Tahitian artist, Vaihere Tauraa, who was invited to explore her understanding of pollution, imagined a delicate and strong body of work, including the following photography and flower crown made out of plastic and fish scales. 

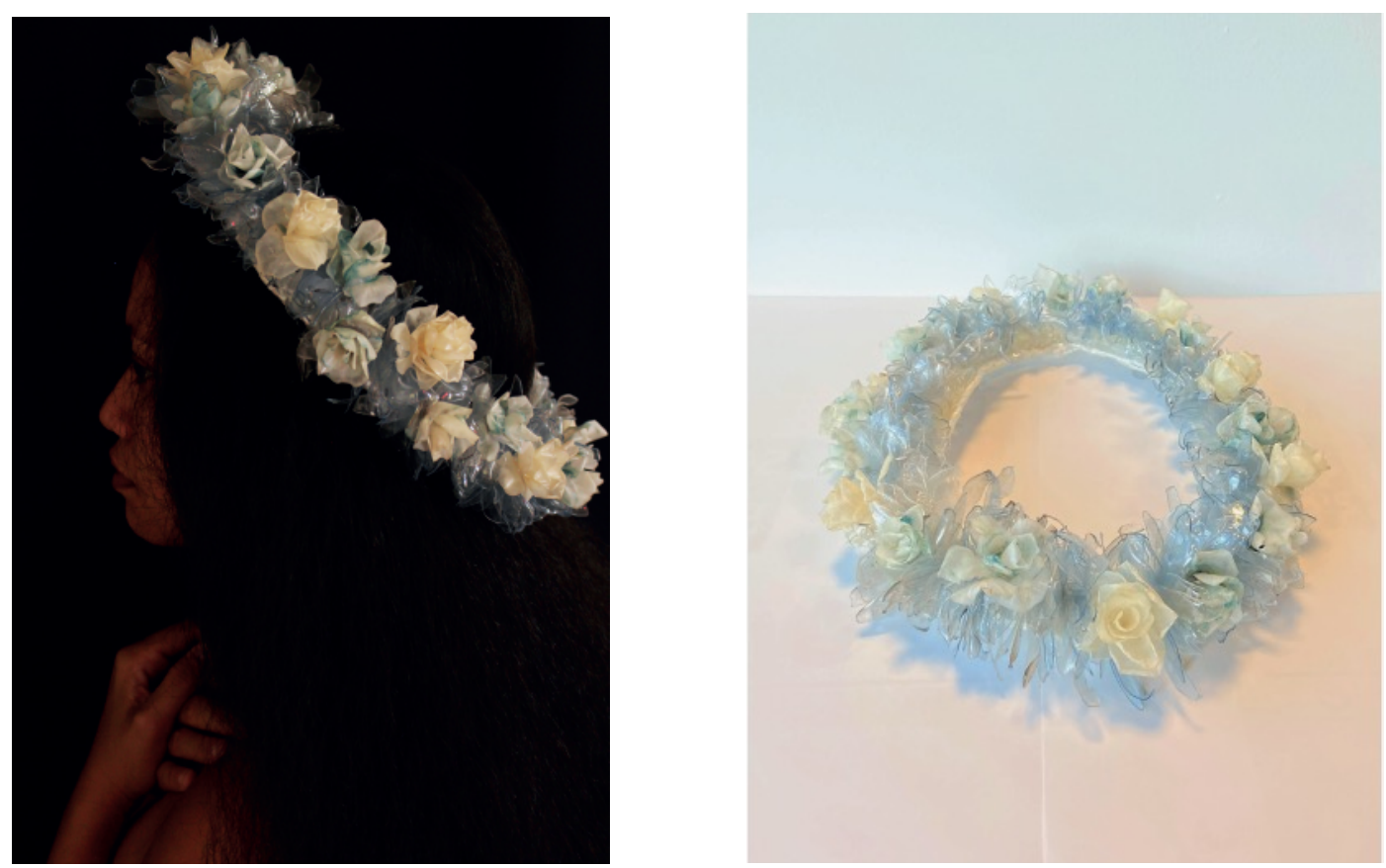

Figure 2 \& 3. Vaihere Tauraa, Hei, photograph, $42 \times 59,5 \mathrm{~cm}$

Vaihere Tauraa, Hei Poa, crown in plastic and fish scale, diameter $30 \mathrm{~cm}$

Her artwork echoes concerned voices, especially those of marine biologists who are alarmed by the very high rates of plastic ingested by marine life, microplastics in the marine ecosystem, and the environmental impact caused by the sourcing and production of plastic. While it is commonly perceived that the recycling process is a new ideal solution, an increasing number of studies show that the recycling of plastic needs to be carefully managed (see Wood et al. in this issue). Macroplastics break down into invisible micro and nano particles (Corcoran et al., 2009) which are most likely a source of persistent organic pollutants (POPs) (Rodrigues, 2018). In creating her plastic and fish scale headpiece, Tauraa pays tribute to her family and community of fishermen who manage their resources in a sustainable way, and encourages a constructive vision for the future.

Bringing about change and envisioning a sustainable future necessarily requires structural political changes. For many Indigenous people around the world, such changes include a recognition of their sovereignty, rights, epistemologies, and "essential cultural values" (Poelina in Voices for the Martuwarra, 2020). Environment might best be described in this issue in relation to the understanding that land is a "living entity" (Watson in Castro-Koshy, 2018). In Voices for the Martuwarra (Madjulla Inc, 2020), Dr Anne Poelina, a Nyikina Warrwa leader, scholar, and the Chairperson of the Martuwarra Fitzroy River Council (Western Australia), explains that seven different Native Title tribal groups came together in 2016 to establish the Fitzroy River Declaration in order to ensure that people acknowledge that "the Fitzroy river is a living ancestral being and it has a right to life" (https://vimeo.com/387436447). This 
declaration belongs to a series of initiatives led by Indigenous people in Australia calling for laws protecting Indigenous water rights. Similar actions were undertaken by Indigenous people in other countries, such as Maori people in Aotearoa-New Zealand who succeeded in having legal personhood granted to the Whanganui River in 2017. This decision was soon afterwards followed by a law granting the same legal rights as a person to the Ganges in India, in 2017.

These landmark legal and structural achievements show the trailblazing roles Indigenous people have had in changing people's mentalities across the globe on how to take care of the earth. These achievements often result from years and decades of campaigns and struggle by Indigenous people and their allies. In Australia, the late Indigenous writer and activist Sam Watson dedicated his life to social justice and Aboriginal and Torres Strait Islander rights. Across Australia and the world, he was known as a writer - one of the first Aboriginal writers to write a novel (The Kadaitcha Sung, 1990) - and a political activist who, in his own words, asserted "his rights as a sovereign Aboriginal man" (p. 34 in this issue). Throughout his life, Sam Watson spearheaded the struggle for the recognition of Aboriginal sovereignty and against the deaths of Aboriginal people in custody or at the hands of the police. ${ }^{4}$ We have the great honour of publishing here - with his family's permission - his powerful, elegiac poem, "Moth", which he sent us for this special issue in August 2019.

The scholars, artists, and writers included in this issue all contribute to answering the question Alexis Wright asked in 2019, "How do [we] find the words to tell the story of the environmental emergency of our times" (Wright, 2019). When we first wrote the call for papers for this special issue, we chose to articulate our main focus around three main themes: "Recycling, perception, and transformation of materials", "Decolonisation and sovereignty as artistic and environmental actions", and "Arts and knowledges of the ocean, sea, rivers, and coastline". As these themes are interconnected, this issue's authors often address two or three themes. ${ }^{5}$

\section{Recycling, perception, and transformation of materials}

Proposals were invited to highlight the symbolic dimensions of new materials, and through the analysis of the negotiations or conflicts that surround their extraction or circulation - to unveil the values given to a territory. This is addressed in the enlightening article by anthropologist and theatre director, Christophe Rulhes, which focuses on illegal gold panning and the play Selve he co-wrote with Sylvana Opoya, a young educated and plurilingual Wayana woman who is the granddaughter of a

\footnotetext{
${ }^{4}$ For further reading on Sam Watson's life and political, literary, and artistic work, see Bailey and Watson (2017), and Castro-Koshy (2018).

${ }^{5}$ The third theme will be a major focus of the forthcoming conference at the University of Bretagne Occidentale, France, in 2021.
} 
shaman (pijai) from Amazonia, French Guiana. Reflecting on the co-authoring process and the organisation and staging of the theatre play in Europe, Christophe Rulhes contemplates the extent to which environmental or ecological concerns have influenced the contributions Sylvana Opoya and her uncle Aimawale Opoya (tipatakem or Taluhwen village chief) made to the play, which addresses extractivism, illegal gold panning, and mercury pollution. Rulhes's article includes video extracts from interviews and underscores that the ways Wayana people talk about environmental concerns are founded on their own knowledge of the ecosystem and have also been influenced by - or deployed in response to - the dialogues they have established over the years with researchers, curators, artists, NGO founders, national park managers, or with filmmakers. The article highlights that most of the young Wayana have been at least once to the city, to the coast, or in Suriname, and how some of them enjoy industrialised foods while others still find pride in their skills as fishermen and hunters. Rulhes eloquently explains that Sylvana's daily life is multilayered and "does not equate to a choice to be made between hope and nostalgia, between two river banks or two worlds. It is a personal, bountiful, and a continuous pluriverse characterised by arborescence and varied opportunities and cracks" (p. 113 in this issue). ${ }^{6}$ This complexity is also found in the relationship Wayana people have with illegal gold panning. Some Indigenous people might work for a time in that field, and later will fight against the destruction of their land. The water is perceived as a treasure but is described as "dirty". Rulhes articulates both the forest and the river as "important matrices of village life". In Taluhwen, the village founded by one of Sylvana's family members, and where she currently teaches, the river provides a place where village members and neighbouring communities gather or trade; "a place to rest, play, meet, discuss, wash oneself, cool down ... wash one's clothes or dishes"; it also provides "fish that people continue eating even though doctors and scientists are advising against it" (p. 115 in this issue). Sylvana explains how plastic waste, different types of packaging, fluids, diesel, mercury, and lead are found in the river and on its banks:

My eyes are burning, my hair is getting damaged, the water is too dirty! When they clean their gold, they don't think about us at all! They leave the mercury that goes into the river, the fish ingest it and we eat the fish and get sick. We all have a lot of diseases because of mercury. Why are the gold panners destroying us? (p. 117 in this issue)

According to the Stockholm Convention, an international convention which was signed in 2001 and became effective in 2004, persistent organic pollutants (POPs) are organic chemical substances that persist in the environment for very long periods of time and are widely distributed as a result of water and soil movements. They

\footnotetext{
${ }^{6}$ For a critical review of the concept of "pluriverse" or "pluriversal", see Glowczewski, 2018.
} 
bioaccumulate in the fatty tissue of living organisms, and are recognized as a serious and global threat to human health and to ecosystems. According to the UNEP (UN Environment Programme), mercury is a highly toxic heavy metal that is harmful to human health and the environment. Indigenous people in Amazonia, for example, are particularly exposed to mercury through eating contaminated fish, which harms the nervous system and leads in particular to heart and kidney diseases. Blocking the construction of new roads, fighting illegal workers, and building barrages are some of the initiatives conducted by the Wayana to prevent the destruction of their habitat, and to protect their health.

Deforestation is a major concern for Indigenous people worldwide. In Indonesia, the Dayak Iban community of Sui Utik [Utik River], Kalimantan, has imagined new creative works based on the materials of the local river and rainforest to challenge deforestation and concomitant problems of air pollution. In her stimulating and well-illustrated article in this issue, architect and lecturer in design studies, Octaviana Sylvia Caroline Rombe, analyses the emergence of social (art) entrepreneurs. Before meticulously describing the fabrication of jewelry, mat and basket weaving, an innovative application of tattoo design "repurposed in the decoration of gourds for the contemporary market" (p. 140 in this issue), indigenous food and beverage processing, the revitalization of traditional hand woven ikat textiles, and the development of small community-based ecotourism, the author depicts the environmental context. Borneo's rainforests are one of the world's richest sources of biodiversity, but despite several alarming reports quoted by Rombe in her article, large scale deforestation continues, with over twenty million hectares of forest lost between 2007 and 2020. In her analysis of interviews with the founder of the local Sekar Kawung foundation, literature reviews, and community summaries, Rombe compares the economic value of logging and timber sales and new eco-craft practices. She describes a successful ecotourism program initiated in the rainforest region of Utik river, including jungle treks that are "held throughout the year while gains from timber sales are temporary, lasting only as long as each logged tree and only as long as the forest trees exist. Thus, the jungle trek program holds an inherent positive influence for the preservation of forests and nature in Sui Utik" (p. 145 in this issue).

Biodiversity and Indigenous communal agrarian technics have been undermined by European colonisation and capitalist markets in many places around the world, especially in the tropics. This is the case in the Caribbean islands, where ecological damage has been wrought by colonialist practices, extensive deforestation, and poor contemporary management. The situation is highlighted in Hannah Regis' article which analyses poems by Caribbean poet, Olive Senior, that address "ecocide, destruction of indigenous ecosystems, ecological plunder and unbridled attitudes of conquest and industrialization" (p. 153 in this issue), while probing the landscape "not only as a site 
of historical trauma but also as a space of agency, sustenance and continuity" (p. 153 in this issue). To set the background for her analysis of Caribbean authors' writings, and of Senior's poems and gardening metaphor in particular, the article starts with a reminder of how the history of modern Caribbean countries is intrinsically linked to the violence inherent in, and caused by, the displacement and annihilation of the region's Indigenous populations, the introduction of slavery and the initiation of indentureship, and historical and contemporary economic exploitation. Referring to the work of Tony Weis, Regis stresses how "Jamaica's ecosystems continue to be irretrievably undone by the demands of neocolonial forces" as deforestation in Jamaica "continue[s] to decrease aquifer recharge systems and underground water levels, alter the hydrological cycle which contributes to harsher droughts, and increase surface runoff" (Weis, cited in Regis, this issue, p. 161). Throughout her article, Hannah Regis deploys a sophisticated argument that highlights how Caribbean intellectual workers and creative writers engage ecological metaphors to "recuperate an alternative history" and "inverse the pain of history" (p. 162 in this issue).

The challenges faced by Indigenous people, and their innovative efforts in attempting to simultaneously protect ecosystems, assert Indigenous sovereignty and continuous presence, and develop economic activities that are compatible with establishing a sustainable future are at the core of a constructive article on managing and recycling marine waste by Jacob Wood, Swathi Paturi, Prerna Puri, Emil Senf Jakobsen, Sumanth Shankar, Pawel Zejden and Simona Azzali. In their research the authors adopt "an integrative literature review approach" (p. 168 in this issue). Wood et al. highlight the paramount importance of protecting Indigenous people's knowledge and territories: "That indigenous people's territories form $24 \%$ of the land worldwide, but contain $80 \%$ of the world's bio-diversity, stands as a testimonial to their sustainable way of living and the importance of safeguarding indigenous territories" (Luoma, cited in Wood et al., this issue, p. 171). As an archipelago, Indonesia is significantly affected by marine pollution. To put this in context, a study by Jambeck et al. calculated that $80 \%$ of the 8 to 12 tons of marine debris that end up in the ocean every year are from inland activities, and revealed that in 2010 Indonesia ranked second after China for mismanaged plastic waste $(2015$, p. 769$)$. Wood et al. have identified several initiatives conducted in Indonesia, Australia, the Philippines, and Nigeria, to convert plastic trash into valuable commodities by recycling and reusing plastic waste in sociocommercial and artistic projects. The authors argue that by doing so, Indigenous communities that are often marginalised by neoliberal ideology not only develop economic opportunities and their own market place, but also assert their sovereignty. The authors also make some recommendations: they argue the Indonesian Government should immediately "enact strict laws to reduce the usage of plastic as an immediate measure" and make sustainable circular economy practices a priority (p. 179 in this issue). 
To inspire change or raise awareness about these issues, an increasing number of artists, internationally, are joining with Indigenous peoples in using varied marine debris. This is the case for Aly de Groot, who weaves with ghost nets or fishing lines. Drawing from her experience as a cultural art worker on Australian Indigenous land, she designs intricate animals as well as thought-provoking art pieces that aim to represent some of the paradoxes of our times.

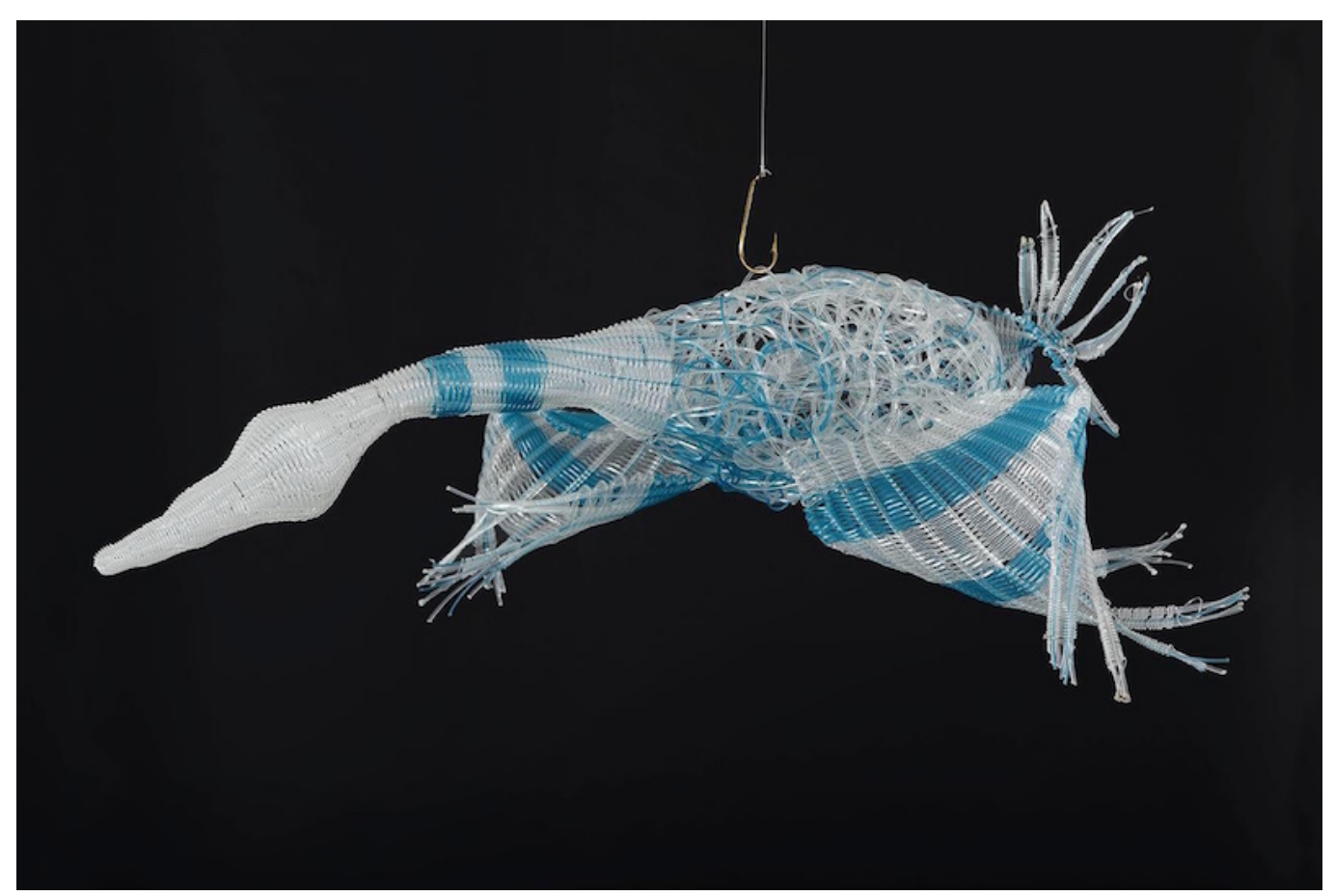

Figure 4. Aly de Groot, Sea Bird 2017, fishing line, fish hook.

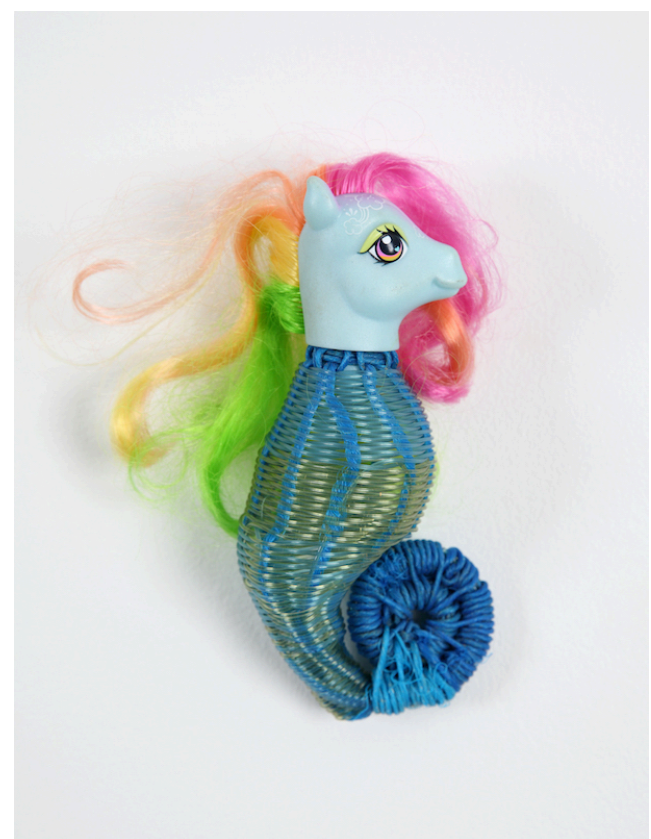

Figure 5. Aly de Groot, Sea Horse, 2019, fishing line, ghost net, recycled My Little Pony toy. 
The need to address plastic manufacture and plastic waste at both individual and government levels is particularly acute for islands subjected to or dependent on tourism. Eating Up Eastern (2019), a film directed by Rapanui producer and director, Sergio Mata'u Rapu, has drawn attention to this critical issue in Rapa Nui. Vanuatu, another Pacific island, took the lead in establishing a formal ban on single-use plastic bags, drinking straws, and styrofoam food containers in 2018 (Visser, 2019).

The eight original poems by Craig Santos Perez, a Chamoru poet from Guåhan (Guam) who is also a Professor of English at the University of Hawai'i, Mānoa, provide a profoundly rich, moving, thought-provoking, and future-oriented offering on the themes we wanted to explore in this issue, and address or allude to many more. In these poems, which on their own constitute a small collection within the issue, Perez deploys a multiscalar and relational poetics that is strikingly effective in its ability to make complexity accessible, the invisible visible, and the (seemingly) distant close and deeply personal. In his first poem, "Age of Plastic", Craig Santos Perez subtly sets the contrast between the prominence of plastic in our lives - specifically during pregnancies (with medical equipment and ultrasound technology) and with raising infants (with baby pacifiers and toys) - and plastic's toxicity for bodies, hormonal systems, the oceans, and the "[w]hales, plankton, shrimp, and birds [who] confuse plastic for food" (p. 43 in this issue). As the poet intermixes familial, intimate scenes with data and discourses about plastic (that appear in italics), the poem suggests that plastic has become so intertwined with our lives that it is encroaching upon them. As the poem ends with an ironic personification of plastic and an unexpected, startling image, it poignantly raises the question of how children will "survive our wasteful hands" (p. 43 in this issue). The poem invites us all to interrogate how we can reverse course, as our inability to address issues of waste and pollution would lead us to our own destruction. With his fifth poem "One Fish, Two Fish", Perez provides a humorous, rhythmic variation on this topic of ocean pollution.

In the poem, "Rings of Fire", Perez again connects the deeply personal - his daughter's birthday, her birth, her first fever - and the global effects and causes of climate change, in particular the fires of California where his parents live. Emphasising "global temperatures, which know no borders" (p. 44 in this issue), this poem also offers another invitation to reconsider our priorities and suggests that our global concern for the planet will only be credible if we concomitantly uphold human rights globally and combat deforestation and wars that are waged for fossil fuels. The poet does not forget how: "Refugees self-immolate at a detention center on Nauru / Forests across Indonesia are razed for palm oil plantations (p. 44 in this issue). Fundamentally opposed to wasting behaviours and lack of care for the land, the poet's father's words and the wisdom learnt from the trees echo throughout his poetry: 
As generations passed, the trees became kin, teaching us how to bend without breaking,

how to create without wasting, and how to take without depleting.

("Tronkon Niyok (coconut tree)", this issue, p. 63)

The notion of "creating without wasting" is central to many Pacific Indigenous practices, such as mat or basket weaving, and the Tahitian tifaifai (Polynesian patchwork). This notion is approached philosophically, artistically, and linguistically in a shimmering poetic-photographic essay by Indigenous Tahitian poet, artist, orator, and academician, Flora Aurima Devatine, who invites readers to draw from their "creative resources". As opposed to natural resources, creative resources are endless, they connect the past, present, future, and allow "ancestral and heritage resources" (p. 90 in this issue) to fill the future with meaning. Aurima Devatine's description of her creative process is an offering to her fellow artists, creators, and to future generations, as she foregrounds that it is within everybody's reach to be creative - in seeing, doing, and thinking. The poet, orator, and artist from Tahiti collected broken and polished pieces of glass bottles which had been thrown to the sea and were "rolled back" by the waves onto the shores. While the glass pieces reveal consumerist societal trends and the unmanageable management of waste, her eye-enchanting photographs "The Work of the Waves", "Mineral Bouquet", "Lolly grains", "Lake landscape", "Pu tifaifai", "Bricks", "Three dimensional ice landscape", "Bamboo garden", "Ocean twirl", "Ice cloud over the sea", "Island shore" - reveal "what draws the eye, captures it", and "what we see, and decide to know" (p. 88 in this issue). Aurima Devatine's focus on the myriad of possibilities offered by what most would see as debris or insignificant pieces (of glass, language, thought) was inspired by her vast knowledge of Tahitian and its polysemic words. HU'A, for example, means, among other things, "very small, minuscule, grain of sand, particle, atom, moss, foam, down, powder, fragment, spark, model, prototype, child, warrior" (p. 70 in this issue) according to the Académie Tahitienne Fare Vana'a, of which Aurima Devatine has been a member since its creation in 1972, and its director since 2017.

The poet invites all Ma'ohi peoples ${ }^{7}$ - the artists, poets, authors, philosophers, thinkers, and everybody else - to transform the pieces ("bris") and debris found in their ocean, on their shores, or in their history, past, memory, and ancestry, into "artwork and stones to lay new foundations" ( $p .71$ in this issue). The poet's wielding of Tahitian concepts and their weaving with French suggests (re)new(ed) ways of empowerment through "resistance, determination, resilience, through arts and poetry" (p. 74 in this

\footnotetext{
${ }^{7}$ Ma'ohi people are the Indigenous people from French Polynesia.
} 
issue). Invited to "write, be creative", the viewer-reader is also encouraged to overcome the commonly reified dichotomy between "ruptures and continuity, life and death" (p. 71 in this issue). As she shares her creative process, the author reveals her worldview embedded in her Indigenous language and offers the reader to see the polysemic nature of Tahitian as a conceptual tool to think the world anew, "project oneself into the future", and respond to difficult questions regarding the possible "erosion of the Polynesian society-canoe" (p. 74 in this issue) and the uncertainties contemporary Polynesian people are facing. Aurima Devatine's poetic-photographic essay is deeply philosophical, it offers hope-filled and innovative ways to understand that "the smallest of things" ("petits riens") can be transformed and polished - by the ocean, the poet, the artist - into beautiful, evocative artworks. It is also a call to understand that the recognition of Indigenous art and artists will also come through the recognition and accepted use of Indigenous words to refer to creativity and creation, among which is the term "te rahu" which refers to the creation of the Polynesian world.

\section{Decolonisation and sovereignty as artistic and environmental actions}

The second theme of our call for papers focused on decolonisation and sovereignty as artistic and environmental actions. In 1995, Australian Indigenous writer, Sam Watson published a powerful piece of non-fiction writing entitled "Turning Point" about Aboriginal deaths in custody, which was sparked by the death of Daniel "Boonie" Yock on 7 November 1993. Yock is remembered, alongside John Pat who died at a police station on 28 September 1983, at the end of Watson's poem "Moth" published in this issue. "Moth" poignantly tells the story of a woman who "has broken no laws" but is also killed by the police. The inhumanity of her death is reinforced by the contextualisation provided by Sam Watson for the poem in an opening preface where a series of facts is listed, and each fact is preceded by a \#. These notes highlight the findings by the Royal Commission into Aboriginal Deaths in Custody that revealed that among the 99 most recent police murders of Aboriginal people, "65 of those deaths were people who were victims of the Stolen Generations" (p. 29 in this issue). ${ }^{9}$ The \# preface also recounts the story of the woman who "had been forcibly removed from her mother when she was less than three hours old.... She spent her entire adult life

\footnotetext{
${ }^{8}$ For biographies of Daniel Yock and John Pat, see the online Australian Dictionary of Biography: http://adb.anu.edu.au/biography/yock-daniel-alfred-18056 and http://adb.anu.edu.au/biography/pat-john-peter15031.

${ }^{9}$ The Royal Commission into Aboriginal Deaths in Custody (1987-1991) investigated Aboriginal deaths in custody over a 10-year period (between 1980-1989). The Inquiry made 339 recommendations. The Stolen Generations refers to children forcibly removed from their Indigenous families. Bringing them Home. Report of the National Inquiry into the Separation of Aboriginal and Torres Strait Islander Children from Their Families (1997) is a 700page report that provides estimated numbers and demographic characteristics of the Stolen Generations members and descendants, and examines the effects of removal from families. It was tabled in Federal Parliament on 26 May 1997 and issued 54 recommendations. The report is available online: https://humanrights.gov.au/ourwork/bringing-them-home-report-1997.
} 
not knowing that she was an Aboriginal child. On that day that she finally came home, her family were at the local hospital. Her mother had died that morning" (p. 29 in this issue). The next part of the poem starts with two lines that convey the atmosphere of a very normal day ("She went into the market"), and the innocence of the woman whose outside-of-time laughter is "as light as the song of a small morning bird" (p. 29 in this issue). The lightness of her song strikingly contrasts with the dooming "eleven minutes and fifteen seconds" (p. 30 in this issue) she has left on this earth. The brutality of a system that not only forcibly removed children from their family but kills coldly is also emphasized by the suddenness of the killing and the robot-like behavior of the kop [cop, police] shooting several bullets into the woman's body. The poem repeats twice:

No crime.

No court.

No jury. (p. 30,31 in this issue)

Throughout the poem, the careful choice of words and rhythm creates a feeling of imminence and seems to echo a pounding heartbeat. The poem gives flesh and pulse to one particular story, which also becomes symbolic of the many stories that are too often only referred to as statistics. The poem foregrounds that colonial violence is an enduring form of pollution in the etymological sense of the term; it is a defilement and a desecration of the land and its sovereign people. With colonisation came "a shroud of bitumen" (p. 33 in this issue) and straight lines, which come to represent British power, law, fences, and inflexibility, and are opposed in the poem to the "circle of ochre" and the "Dreaming Line" (p. 32, 30 in this issue). While the poem is infused with sadness and the harrowing weight of the "broken unmapped pain" (p. 30 in this issue) the woman suffered throughout her life, it remarkably holds both an elegy and a comforting, empowering song together. It is indeed a tribute that is also re(-)membering this "woman of the desert", who "carried the songs and the truth of the desert deep within her own spirit" (p. 30 in this issue). As is characteristic of Watson's writing, her killer and colonisation are not victorious; "the never ending story of the land", the story that "never dies" (p. 33 in this issue) belongs to Aboriginal people, as:

The Old People sing and they dance amongst the stars

As she walks into the high Dreaming Place on silken feet.

There will be a feast. There will be a gathering.

There will be stories told and there will be laughter.

No more pain now. (p. 32 in this issue)

While Sam Watson's gripping poem confronts colonial and structural violence, Yvette Holt's poetics disarms them. Brisbane born Yvette Holt, who heralds from the Bidjara, 
Yiman and Wakaman Nations of Queensland includes two thought-provoking and imagination-inspiring poems in this issue that are accompanied by splendid photographs. In the poem "spinifex scriptures", the first stanza "old testament" (p. 36) foregrounds the strength of the Aboriginal way of life in the desert, the fundamental importance of relationships and stories passed down. This first stanza is about deep time, time immemorial, abundance, and about being. The second stanza, "new testament", conversely, speaks to car-related pollution, actions with a limited timespan, and a materialistic view of the world where relationships have vanished or been effaced. While these motor cars can be imagined and visualised in the desert through the accompanying photographs, they can also be read as a metaphor for contemporary times ruled by short timeframes, short-sightedness, disposable objects, and for the waste caused by settler colonialism. On the one hand, the poem can be read as being about the chasm between the old and the new, the past and the present, Indigenous lives before colonisation and those in the twenty-first century. On the other hand, it is possible to understand that through the poem, the old and the new are held together; the communal life of the old reaches through new times; the new does not cancel the old and would not exist without the old. The poet makes sure we know the old testament has not disappeared as it sets the foundation for the poem. The poem can also be read as playful, as its last word seems to indicate. Playing on the sound of words, the poet signals that resilience and strength are her preferred ending.

The myriad ways through which cars can pollute the environment, and also become part of it, is captured through both the poem and the photographs - which draw the viewers into the land(scape). Although the photographs accompanying "spinifex scriptures" make a statement about car pollution in the desert, and can be read as the impact on desert life of colonisation and modernity, the titles accompanying the photographs are also the names of places. The photographs are therefore subtended by all the stories that led the cars or car parts to be left in these specific places, and open into lives, and perhaps deaths, that are not visible here but have traversed these parts of the desert. While there is an uncertainty regarding what happened to the people who were in the cars, the ever-present country "can wait for eternity" (Wright, 2018), and will cover the debris with its red dirt (see Figure 2. "Tanami Highway" p. 37 in this issue). What is made visible by the photographs is the permanence and beauty of the land, the way it paints on metals, just like the poet-photographer draws with her words, eye, and lens. With the image "Old Mt Allen Pastoral lease 1", the sky and the cloud seem present on the upper car. On "Santa Teresa 3", the spinifex expands its territory. Photograph "Yuelamu 7" suggests that life can emerge and blossom from the most improbable places (p. 38 in this issue). It also provides a visual meditation on what it means, and what it takes, to magnify. The dialogue the photographs establish with the poem therefore provokes new readings for "spinifex scriptures". This is also the case in Holt's following poem. 
In "desert analysis" (p. 39-41 in this issue), Yvette Holt allows us to pay greater attention to the poetry of the desert, where her photographs have also captured how the land is alive. The photographs might also allude to the fact that the scarcity of water in the central desert has to do both with atmospheric pollution - and therefore climate change - and the pollution of the land and water resources brought about by pastoral and mining industries. The poem and photographs certainly focus on the multidimensionality of narratives in the desert, on the porosity of so-called frontiers between the skies and the sand, the ocean and the desert, as mountains are swimming and "curlew climbs / softly drowning / high above / ceramic clouds" (p. 40 in this issue). Through a conversation between the two artistic media, the "speechless waters" are evocative of the vibrant pull of life in this ecosystem, and "analogue tongues" are invited in a dialogue between the infinitely small and immensity. Both the enigmatic dimension of the poems, and the interpretative freedom Holt is giving to her reader to participate in her life-imbued, enticing poetics, also remind us that sparseness makes room for the imagination.

The original poetic pieces published in this issue, and the poems by Olive Senior studied by Hannah Regis, share a commonality: they are the places of multiple echoes. The writers' ecopoetry is also an echo-poetry. Watson's poems resonate with echoes from the desert, the past, the ancestors, and the lives of Indigenous people who were lost at the hands of state-sanctioned policies or the police. Holt's poetry and photographs echo the beauty of the land, survival, and songlines. Sarah Moore's pluridisciplinary work, which is discussed below, echoes the power of songs and the (Indigenous) art of storytelling through her artistic practice focusing on the oyster, which invites us to understand how coastal Aboriginal cultures conceptualise the connectedness of land and sea to form people's "Country". ${ }^{10}$ Throughout Perez's poems, love, knowledge, his Indigenous language, and - creation, ancestors', family - stories echo between the generations, while undefeated political struggles echo from one battlefield, such as Standing Rock, to all the places in the world where water is endangered ("Water is life!", this issue, pp. 47-49).

All the creative pieces featured in this special issue are an invitation for a change in our mentalities, behaviours, and relationships. An encouragement to understand that the plastic crisis, climate change, pollution and wars due to the fossil fuel industry and water scarcity impact all of us at the personal and most intimate level. Perez brings nuanced awareness that these issues are not distant to us, they affect our family lives. With "Halloween in the Anthropocene" (p. 46 in this issue), Craig Santos Perez uses a provocative title and familiar, playful scenes to bring attention to the interrelatedness between the complacent choices we make for amusement and the devastating impact

10 "Country" is a term used in Australia to refer to the ancestral lands of Aboriginal and Torres Strait Islander people. 
of the extractive industry, children in poverty, and new forms of slavery in Africa, Asia, and for Indigenous people. Connecting the struggle against colonisation, capitalist exploitation, and the degradation of the environment, the poem interrogates our responsibility toward the suffering of people who are exploited, "the sacrificed"; it also issues a warning as our actions today are paving the future of the next generations: "even tomorrow will be haunted" (p. 46 in this issue).

In Perez's powerful poem, "Chanting the Waters" dedicated to "the Standing Rock Sioux Tribe and water protectors around the world" (p. 47 in this issue), the poet chants that when we participate in the pollution of the earth, of our waters, we participate in the pollution of our own bodies - "because our bodies are 60 percent water", "because our hearts are 75 percent water", "because our planet is 70 percent water", "because our bodies won't survive a week without water" (pp. 47-49 in this issue). The poet chants how essential water is, how it is misused, used for profit, wasted, and - we can hope - helps us realise, that wherever we look, water is everywhere, creating, allowing life, and connecting all people. The poem also emphasises that to be listened to, to create change, Indigenous people will keep repeating the most fundamental facts, their stories, and assert their sovereignty - over the land and the water - over lines, over weeks, over years, as at Standing Rock, and decades, as in Guam, his home island, where "military property ... includes about one third of the island" "Tronkon Niyok (coconut tree)", this issue, p. 67). The poet also pays a heartfelt tribute to all the Indigenous people who "say stop! keep the oil in the ground", and face "banks and politicians and dogs and paychecks and pepper spray and bullets", "their police and private militia" (p. 48 in this issue). And yet, Perez asserts, "we are not moving", "we bring all our relations and all our generations and all our livestreams" (p. 48 in this issue). The poem is a strong reminder that people risk their lives to defend their territory, and defend, for the whole planet, that "water is life". ${ }^{11}$ With his selection of poems, Perez's ec(h)o-poetry moves: it moves the heart, it moves on the page, it follows the ebbs and flows of the ocean and the rivers, of Oceania and its "transoceanic / past present and future / flowing through / our blood" ("Praise Song for Oceania", p. 51-55 in this issue), of the contracting waves of labour, and of the political movements of Indigenous people and their allies.

Hannah Regis's article also sheds light on Senior's ec(h)o-poetry, as she analyses how Senior engages "echoes from history" including ancestral cosmologies in a "wounded landscape" that is also "littered with human bones" (p. 158 in this issue). Regis foregrounds that for Senior, the Caribbean landscape is both "the original archives", "a surviving witness to the colonial past", and "an active and creative agent",

\footnotetext{
${ }^{11}$ See also Glowczewski 2017, p. 18 and https://nlginternational.org/2020/08/video-indigenous-peoples-and-thestruggle-against-extractive-industry/ on the threats faced by Indigenous people, their imprisonment, and their assassinations.
} 
which engenders at the same time memories of dispossession and a "possibility of rebirth of peoples and environments" (p. 153, 159 in this issue). The scholar demonstrates how Senior's poetry provides empowering ways to redefine Caribbean cultural identity as it seeks both to establish a "more meaningful sense of ontological grounding" and work against "the fragmentation of Caribbean identity and belonging" (p. 154 in this issue). As Regis examines Senior's poem, "Brief Lives", for example, she highlights that "ancestral blood and skeletons refuse to remain buried, and resist permanent erasure", thus showing that "the landscape has memory and can yield an uninterrupted flow of healing knowledge into the stream of everyday occurrences" ( $p$. 158 in this issue).

For this issue, we wanted to look at Indigenous concepts used by artists to express their vision of what "sustainable development", or a respectful relationship with the environment, would be. Octaviana Rombe's article discusses how in Indonesia the Dayak Iban community of Sui Utik, Kalimantan, demonstrates the ecological and economic value of the Indigenous system of Tembawang, which implements and reflects a complex understanding of conservation based on protection, preservation, and utilisation. The system not only "retains and restores indigenous rainforest flora" (p. 145 in this issue), thereby reinforcing the diversity of the local rainforest; it also challenges deforestation and air pollution through creative works based on the materials of the local rainforest. Tembawang is a land use system of the Dayak peoples of West Kalimantan, Indonesia, which incorporates various types of plants and agricultural techniques in accordance with local wisdom and social rules. "In addition to maintaining ecological systems and biodiversity, the system also retains cultural heritage, indigenous knowledge, and spiritual practices - all of which are passed from one generation to the next" (p. 129 in this issue). Recalling anthropologist Soeharto who stated that Tembawang "contains values that are very sublime" (Soeharto, cited in Rombe, this issue, p. 129), Rombe emphasises the pleasure derived by the community in producing creative works that are beautiful and demonstrate specialised skills; for example, a weaver named Mamak Bayu did not intend to sell a beautiful mat she had woven because she fell in love with the piece.

Indigenous practices and livelihoods are also addressed in an article on Malaysia by Kavitha Ganesan, Anantha Raman Govindasamy, Jane Wong Kon Ling, Shaffarullah Abdul Rahman, Kennedy Aaron Aguol, Jamsari Hashim, and Bilcher Bala, which features in the varia section. Malaysia, whose Indigenous peoples were estimated in 2017 to account for around $13.8 \%$ of the national population of $31,660,700$ million (IWGIA, 2020), is a country facing numerous environmental challenges. Kavitha Ganesan et al. discuss how the Lundayeh minority in the state of Sabah, Malaysia are able to retain their indigeneity and lay a claim to their Lundayeh sovereignty "through traditional food practices" (p. 206 in this issue). Drawing on previous work conducted 
twenty years ago by Hoare (2002) and Vaz (2006) on the challenges caused by deforestation, logging, and road infrastructures, which also examined how the villagers in Long Pasia both endured and contested the rapid changes occurring around them, the co-authored, interdisciplinary, article provides a stimulating analysis of hunting techniques, agricultural cooperative work, complementary gender roles, religiously sensitive food adaptation practices, waste management, and food storage. It demonstrates that "the Lundayeh's relationship with the land endures, which in turn, secures the community's indigenous identity" (p. 200 in this issue). The ethnographic documentation by Ganesan et al. highlights a "zero wastage principle" (p. 213 in this issue) made possible by the longhouse infrastructure and its associated social rules, and describes a system of fallow land which also uses buffalo dung to fertilise paddy fields. The discussion, founded on their field-based studies, addresses current conflicts around deforestation and adjustments made, for example, to the locals' hunting methods as a result of deforestation. It also highlights how the forest makes hunted meat "sufficiently palatable", and how today's food preparation has changed as the Lundayehs use salt that is bought in villages now easily accessible by car instead of distinctive "affa" leaves - as well as monosodium glutamate (MSG) and other flavourings. Additionally, the scholars aptly demonstrate that paddy cultivation "is not just about food production. It is a cultural marker" (p. 213 in this issue). They highlight, in particular, that the variety of the rice grain planted in the village in Long Pasia has "a unique texture and taste due to the soil and 'red water of the Sia River" and that "cultivated rice is still treated with high esteem because it represents the relationship that the community has secured with the land from one generation to another" (p. 212 in this issue).

Jean Anderson, in her illuminating essay, also focuses on colonial as well as multinational interference with Indigenous food practices. She "takes a broad view of recycling to explore ways in which Indigenous artists in the Pacific make use of repurposed materials to criticise some of the profoundly unsettling - and enduring effects of colonisation" (p. 186 in this issue). The essay examines a wide range of artistic expression and works by Michel Tuffery, Craig Santos Perez, Kathy JetñilKiijner, Jean-Daniel Tokainiua Devatine, Misa Tupou, 'Ofa Guttenbeil-Likiliki, James (Jim) Vivieaere, Seth (Julien Malland) and HTJ. The breadth of the essay allows the author to foreground the diversity and depth of innovative, political, vibrant, and imaginative artworks that address crucial environmental, political, and food issues affecting the health and well-being of Indigenous populations in the Pacific, and in particular in the countries where the artists and writers hail from: Aotearoa/New Zealand, Tahiti, Samoa, Kuki Airani, Guåhan (Guam), the Marshall Islands, Tonga, and the Cook Islands. These issues include the over-consumption of corned beef in Samoa and over-fishing of tuna (Tuffery), heart disease and U.S. military presence in the Pacific (Perez), food colonisation that might ultimately become self-enforced and 
the loss of alimentary independence (Jetñil-Kijiner and Devatine), the deleterious effects of the importation and consumption of multinational sugary soft drinks (Tupou), the scarcity of drinkable water and rising sea levels (Guttenbeil-Likiliki), absurd and belittling colonial representations and categorisations (Vivieaere), and the devastating nuclear tests that took place in French Polynesia (Seth and HTJ). As Anderson deftly moves between formal and thematic analyses, she shows how these artists, by "repurposing objects, which equates to a radical alteration of their context, creat[e] new readings of both the objects and their original context" (p. 186 in this issue). She argues for a reading of works such as Tuffery's Pisupo Lua Afe (Corned Beef 2000) and Tupou's piece, A Choice of a New Generation, as "powerful indictment", and uncovers a political, decolonial reading of Tahitienne en rouge, a mural designed by French artist, Seth (Julien Malland), and Indigenous French Polynesian artist, HTJ. Taking up Nicholas Thomas's proposition that reappropriation is used by artists "to turn the tables" and "defines the Polynesian artist as a critical commentator" (Thomas cited in Anderson, this issue, p. 195), she emphasises that the artworks under study are "speaking back" and are marked by "the assertion of resistance and difference" ( $p$. 195 in this issue).

Indigenous French Polynesian sculptor and poet, Tevaite Rey, Blouin, Vehiatua, Tupai a Ma'au also encourages viewers to think about the different sources of pollutions and their global impact through her creative appropriation of the fan (tahiri), one of Polynesia's most iconic objects, and a moving poem she wrote especially for this issue. Tevaite Rey first created the fans in response to the pollution theme chosen by Géraldine Le Roux for the 2019 exhibition, Maeva. Polynesian Contemporary Art from Tahiti and French Polynesian islands. For the exhibition, Rey slightly modified the materials and dimensions of this emblem of prestige, and reduced its thickness to illustrate the great pressure exerted by humans on natural resources. In this issue, Rey's art-poem piece pays homage to the richness of Polynesian epistemology techniques, from which she draws her inspiration, to respond to the ecological state of the world. The poem also underlines the complexity of her feelings as she navigates her angst, guilt, feelings of powerlessness, and desire to act, even as she comes to the realisation that she does not know where to start.

Tes cris de souffrance résonnent dans mon corps

Je transpire ton mal être

C'est de ma faute, je te rends malade.

Je vis à ton détriment

Pourtant, je ne suis rien sans toi

Tu m'oxygènes, me nourris, m'abreuves, me laves et me soignes

(p. 66 in this issue) 
Your cries of suffering echo in my body

Your unwell state I am perspiring

This is my fault, I make you sick

I live at your expense

And yet I am nothing without you

You give me oxygen, food, drink, wash me and heal me

Tevaite Rey longs for the knowledge and the answers to her questions that her own elders could have passed on if they had not been so preoccupied with teaching the new generations how to survive in the globalised world. As they cannot provide the guidance she would have hoped for, she pays tribute to the knowledge-holders of the small islands of the archipelagos of French Polynesia who have inspired her. The poem invites the reader on an open-ended journey thanks to the series of questions it raises, especially on the values and lifestyles we espouse today and on the consequences of an industrialised and globalised world. It suggests, in particular, that we urgently need to rethink our mechanisms of solidarity and responsibility. Although Rey feels her ability to combat climate change and pollution is "minuscule", her majestic tahiri sculptures and open-ended poem, which weave together Polynesian intangible and tangible heritage, encourage us to think that pressing upon cultural values might be an appropriate response to eschew the empty, misleading promises of infinite consumption and economic growth.

For this special issue on Environmental Artistic Practices and Indigeneity, we were particularly interested in receiving contributions that enter into dialogue with works conducted by Indigenous academics, researchers, and artists. Sarah Moore's contribution shows the fruitful potential of such collaborations. She has collaborated with Aboriginal Wirajuri marine biologist, Laura Parker, whose work in climate proofing the Bandangi (Eora language) or Sydney Rock Oyster of Australia "stands as testament to a deep passion for saving a species" (p. 98 in this issue). Through essay, story, poetics, music, a song, and a visual artwork, Sarah Moore invites us to look at oysters and to "explore the opportunities and possibilities that worlding with nature and regarding mother earth as our healer offer to communities of practice" ( $p .97$ in this issue). Moore, for example, beautifully describes that during "its early life, the Bandangi swim around in the water column and change shape multiple times. Whilst the oysters are becoming, they are fluid, transformative and mobile; they dance!" ( $p$. 100 in this issue). After settling in an appropriate spot, they "act as a biological filter to purify polluted estuarine water and are a food source for other marine organisms and birds" (p. 100 in this issue). Shells have often been studied attentively by artists such as author, Marc Le Gros, from Brittany, France, who wrote Éloge de la palourde (2017) (Homage to the clam). However, Moore's text and song shed light on the values and intangible heritage associated with particular countries and on the learning that can 
ensue from engaging with the "watery worlds" that First Nations peoples have "storied" since ancestral times. She underlines, for examples, "the value of learning through everyday experiences with the more than human", and explains that middens are "keeping places for traditional cultural knowledges" and "d[o] not lay the story of waste, but embod[y] tangible, deep and rich histories and ways of interpreting" (p. 98, 99 in this issue).

Founded upon an assertion of Indigenous sovereignty, Sarah Moore's Worlding with Oysters encourages readers to think about both a precolonial time and a healthy future "rich with connection, community and collectivism", and "to imagine a time when whales come back to safe harbours; when oysters spawn in pristine waters and when the smoke of old campfires is remembered as an essential element of the conceptualisation of caring for Sea Country" (p. 97 in this issue). Malcom Ferdinand demonstrated in his book Une écologie décoloniale. Penser l'écologie depuis le monde caribéen (2019) that it is necessary to think ecology and politics in an integrated way, and, in particular, to examine how colonial processes have impacted the bodies and the environment. Moore's pluridisciplinary and multi-art approach provides an example of the fruitfulness of such an integrated way. After acknowledging that "[t]he silencing of family stories, the trauma of the Stolen Generations, the disempowerment caused by systemic racism and the removal policies of Aboriginal children from their families" have all contributed to the disruption of relationships and of the transmission of knowledge and culture on Sea Country, she creatively and conceptually treats oysters as a metaphor for old knowledges, "a vessel for ancient stories and a safe harbour for unique and valued environmental teachings to find shelter and sustenance" (p. 99 in this issue). The academic and creative contributions for this issue all highlight the necessity to look back at the old stories and ancestral laws which "can be political and yet equally healing" (Martin cited in Moore, this issue, p. 99). They therefore reveal the importance of knowledge and story transmission, not only at the individual family level, but through communities of people, learning, and practice.

\section{Conclusion}

The essay "Worlding with Oysters" by Sarah Jane Moore was written in June 2020, three months after the World Health Organization officially declared the new coronavirus COVID-19 outbreak, a pandemic. The worldwide circulation of the coronavirus has highlighted - and exacerbated - situations of inequality and social and environmental injustice. The structural lack of access to health care, pre-existing health conditions such as respiratory diseases, and economic vulnerability, were conditions for the spread of this virus in Indigenous communities. For example, in the United State, by May 2020, the Navajo Nation, who has only 12 health centres on a $72,000 \mathrm{~km}^{2}$ territory, had a higher rate of contamination than the city of New York 
(Bellier, 2020). In Amazonia, the crisis brings back the painful memory of previous diseases introduced by explorers, missionaries, and workers (Bellier, 2020). The destruction of the ecosystems (forests, waterholes, coastlines, and their associated species), the construction of roads and infrastructures, and the imposition of new economic models, have led to the abandonment of communal or small gardens, horticulture, and to the introduction of industrialised and processed foods. Many scientists and environmental activists argue that deforestation and climate change allows for the zoonotic transfer of new viruses from animals to humans. Additionally, this recent crisis has also shown that in communities where Indigenous people have a certain level of self-determination and can control their borders and temporary close them, as in some parts of Australia, they have been able to stop the spread of the virus and protect their people.

With the ability to create effectively strong images, visuals, words, videos, and songs, artists and writers can anticipate or echo the cries of urgency that so many scientists worldwide have expressed. This issue features a significant range of calls for action to better protect and restore ecosystems. As this issue is going to publication in 2020 - only months after devastating fires in Australia, Alaska, and Amazonia, and at a moment when California is experiencing some of its largest historical fires conversations about the need to listen to Indigenous people's knowledge on how to care for the land are being voiced, and heard, on mainstream media (Wright, 2020; Sommer, 2020). Malcom Ferdinand, in interview, highlights that "colonial habitation"12 is a violent way to inhabit the Earth as "it enslaves the lands, humans, and nonhumans" and subjects them to the colonisers' whim (2020, p. 52). Refusing or combatting such violence, this special issue's authors all provide "hope-filled and hopeful" (Moore, p. 96 in this issue) examples of projects engaging with Indigenous lands, rivers, waters, and the environment in a respectful way, and in solidarity with Indigenous people. All the contributions featured here are meaningful because they invite us to listen, to think about the beauty of specific places or the pain caused by traumatic events and histories, to confront paradoxical events or behaviours. Like Craig Santos Perez's father, they are asking to "Take with gratitude, / \& never more than / what you need." ("Family Trees", p. 57 in this issue). They encourage people to keep on, or to start looking after their environment, and to be committed to social and environment justice. As such, they hold the potential to change our lives, just like a group of young Indigenous people gathered at the Garma festival in the Northern Territory of Australia in $\mathbf{2 0 1 9}$ who declared in their "Imagination Declaration", "It's time to think differently". ${ }^{13}$

\footnotetext{
12 "Colonial habitation" are the terms chosen to translate "l'habiter colonial" by Anthony Paul Smith for the translation of Ferdinand's book, Une écologie décoloniale. Penser l'écologie depuis le monde caribéen, to be published by Polity Books.

${ }^{13}$ For a contextualisation of this declaration, see De Largy Healy, 2020.
} 


\section{References}

Aurima Devatine, F. (Forthcoming). Des fragments de vers, HU'AHU'A PEHE, et des bris de verre, HU'AHU'A MOHINA. In 'Ōrama, Tahiti, Polynésie française. 'Ōrama Studio, pp. 76-91.

Bailey, D. H., \& Watson, S. (2017). CityCat Project 2006-2016. Eds D. Prestorius, R. Butler, S. Butler, M. Heimrich, Berlin: Sternberg Press in partnership with Australian Fine Arts/David Pestorius.

Bellier, I. (2020, May). Les peuples autochtones face au Covid-19 : un tour d'horizon au 20 mai 2020. Retrieved from http://gitpa.org/web/200522\%20ArticleIBPACOVID.pdf

Bellier, I. (2013). Introduction : La reconnaissance internationale des peuples autochtones. In I. Bellier. Peuples autochtones dans le monde : les enjeux de la reconnaissance. L'Harmattan, pp.13-40, 2013, Horizons autochtones, 978-2-343-01120-2. Retrieved from: https://halshs.archives-ouvertes.fr/halshs-01017391

Bergmann M. L. G. \& Klages M. (2015). Marine Anthropogenic Litter. Springer Cham. DOI: 10.1007/978-3-319-16510-3

Castro-Koshy, E. (2018). An Interview with Sam Watson. AustLit. Retrieved from https://www.austlit.edu.au/InterviewSamWatson

Chen C-L. (2015) Regulation and Management of Marine Litter. In M. Bergmann, L. Gutow, M. Klages (Eds) Marine Anthropogenic Litter (pp.395-428). Springer, Cham. https://doi.org/10.1007/978-3-319-16510-3 15

Corcoran, P. L., Biesinger M. C. \& Grifi M. (2009). Plastics and beaches: A degrading relationship. Maritime Pollution Bull 58, 80-84.

De Largy Healy. J. (2020). La déclaration de l'imagination ou l'appel au rêve de la jeunesse australienne. Cahiers de littérature orale. Hors Série.

Derraik, J. G. B. (2002). The pollution of the marine environment by plastic debris: a review. Maritime Pollution Bull 44, 842-852.

Duclos, M. (2015). Horizons d'égalité. Le combat des biffins parisiens. [PhD Dissertation]. Paris Sorbonne.

Ferdinand, M. (2019). Une écologie décoloniale. Penser l'écologie depuis le monde caribéen. Seuil.

Ferdinand, M. (2020). Pour une écologie décoloniale. Malcom Ferdinand, Propos recueillis par Aurore Chaillou, Louise Roblin, C.E.R.A.S. Revue Projet. 2020/2 º375, pp. 5256.

Galgani, F., Hanke G. \& Maes T. (2015). Global Distribution, Composition and Abundance of Marine Litter. In M. Bergmann, L. Gutow \& Klages (Eds) Marine Anthropogenic Litter (pp. 29-56). Springer Cham, DOI: 10.1007/978-3-319-16510-3, pp. 29-56.

Garcier, R. J. (2014). Disperser, confiner ou recycler? Droit, modes de gestion et circulations spatiales des déchets faiblement radioactifs en France. L'Espace géographique 43 (3), 265-283.

Glowczewski, B. (2018). Le pluriversel à l'ombre de l'universel. Terrestres. Retrieved from : https://www.terrestres.org/2018/11/15/le-pluriversel-a-lombre-de-luniversel/

Glowczewski, B. (2017). Standing with the Earth. From Cosmopolitcal Exhaustion to Indigenous Solidarities. Inflexions 10, 1-24 www.inflexions.org

IWGIA (n.d). Indigenous Peoples in Malaysia. https://www.iwgia.org/en/malaysia

Jambeck, J R., Geyer, R. Wilcox, C., Siegler T. R., Perryman M., Andrady A., Narayan R. \& Lavender K. L. (2015). Plastic waste inputs from land into the ocean. Science 347(6223), 768-771. http://doi.org/10.1126/science.1260352

Joulian, F., Tastevin, P. \& Furniss, J. (2016). "Réparer le monde" : une introduction. Techniques \& Culture 65, 14-27. doi http://journals.openedition.org/tc/7772 
Keown, M. (2018). Waves of destruction: Nuclear imperialism and anti-nuclear protest in the indigenous literatures of the Pacific. Journal of Postcolonial Writing, 54(5), 585-600. http://doi.org/10.1080/17449855.2018.1538660

Laviolette, P. (2006). Ships of Relations: Navigating Through Local Cornish Maritime Art. International Journal of Heritage Studies, 12(1), 69-92.

Lebreton, L. C. M., van der Zwet, J., Damsteeg, J.-W., Slat, B., Andrady, A., \& Reisser, J. (2017). River plastic emissions to the world's oceans. Nature Communications, 8 , 15611. https://doi.org/10.1038/ncomms15611

Le Gros, M. (2017). Éloge de la palourde. Clermont-Ferrand : La Nouvelle Escampette Editions.

Le Roux, G. (2016a). Twenty thousand nets under the sea. In L'art des ghostnets, exhibition catalogue, Paris : Arts d'Australie-S. Jacob Edition.

Le Roux, G. (2016b). Transforming Representations of Marine Pollution. For a New Understanding of the Artistic Qualities and Social Values of Ghost Nets'. In E. Castro-Koshy \& G. Le Roux (Eds.) Visual Creativity and Narrative Research in and on Oceania [Special Issue] AnthroVision, 4(1), 1-20. https://doi.org/10.4000/anthrovision.2221

Madjulla Incorporated. (2020). Voices for the Martuwarra [Video]. Martuwarra Fitzroy River Council https://vimeo.com/madjulla

Mata'u Rapu, S. (Director) (2019). Eating Up Eastern [Documentary Film]. Kartemquin Films.

Rathje, W. \& Cullen, M. (1992). Rubbish!: the Archaeology of Garbage. Harper Collins Publishers.

Rickard, J. (2017). Diversifying Sovereignty in the Reception of Indigenous Art. Art Journal, 76 (2), 81-84. https://doi.org/10.1080/00043249.2017.1367194

Rodrigues J. P., Duarte A. C., Santos-Echeandía J. \& Rocha-Santos T. (2018). Significance of interactions between microplastics and POPs in the marine environment: A critical overview. Trends in Analytical Chemistry 111, 252-260 http://doi.org/10.1016/j.trac.2018.11.038

Schlosberg, D. (Director) (2019). The Story of Plastic, [Documentary Film]. The Story of Stuff Project \& React To Film.

Sommer. L. (2020, August 24). "To Manage Wildfire, California Looks To What Tribes Have Known All Along". NPR/KQED. Retrieved from: https://www.kvpr.org/post/managewildfire-california-looks-what-tribes-have-known-all-along

Visser, N. (2019, February 24). Vanuatua has one of the world's strictest plastic bans. It's about to get tougher. Huffingtonpost. Retrieved from https://www.huffingtonpost.com.au/entry/vanuatu-plastic-ban-law-ocean-pollution

Watson, S. (1994, November 19, 1995). "Turning Points", The Age, republished in G. Reilly (Ed.). My First Love and Turning Points (pp. 127-31). Victoria, Julie Morgan Marketing.

Wright, A. (2018, Jan 25). Hey Ancestor! The Guardian. Retrieved from: https://www.theguardian.com/commentisfree/2018/jan/26/alexis-wright-hey-ancestor

Wright, A. (2019, May 17). We all smell the smoke, we all feel the heat. This environmental catastrophe is global. The Guardian. Retrieved from: https://www.theguardian.com/environment/2019/may/18/we-all-smell-the-smoke-weall-feel-the-heat-this-environmental-catastrophe-is-global

Wright, A. (2020, Jan 15). Want to Stop Australia's Fires? Listen to Aboriginal People. New York Times. https://www.nytimes.com/2020/01/15/opinion/australia-fires-aboriginalpeople.html 


\section{Acknowledgements}

We would like to thank Associate Professor Anita Lundberg, eTropic Editor-in-Chief, for her great professionalism and editorial acumen, and Jasmin Peer, for her assistance with formatting aspects of this issue.

Dr Estelle Castro-Koshy is a scholar of Indigenous Australian and French Polynesian literary and cultural studies. She is an Adjunct Senior Research Fellow at James Cook University. Her recent publications include a review of Lisa Bellear's Aboriginal Country (https://foame.org/home/article/review-from-you-to-me-to-you-from-me-its-astart-heart-to-heart-by-lisa-bellear/) and an essay co-written with Philippe Guerre entitled 'IIn My Mind I See Cross-Roads for Everything I Believe In': The Way Home in Alexis Wright's Croire en l'incroyable (Believe in the Unbelievable) and Le Pacte du serpent arc-en-ciel" (Antipodes, 2019). She was a co-founder of the first Oceanian Writers' Festival in France (2014). Her translation of Wisdom Man was a runner-up for the "Revelation" Translation prize from the French Society of People of Letters in 2018. She is currently editing a book on the work of Indigenous Tahitian poet, orator, and academician Flora Aurima Devatine.

Dr Géraldine Le Roux is a Senior Lecturer of Anthropology and the co-Director of the Department of Ethnology at University of Western Brittany, France. She is also an Adjunct Senior Research Fellow at James Cook University. Géraldine Le Roux works as a freelance curator and has organised several exhibitions and artist residencies in France and Belgium, including events promoting Australian Indigenous and Pacific arts. Her major research fields include anthropology of art, with particular attention to art production and reception in cross-cultural contexts. Her most recent research and publications focus on ghostnet art, an artistic intervention engaging with marine pollution. She is currently completing a book on ghostnets entitled Des filet-fantômes et un art des ghostnets. Approche anthropologique et esthétique des déchets marins. 